\title{
Neonatal mortality in infants with low birth weigh
}

\author{
MORTALIDADE NEONATAL EM CRIANÇAS COM BAIXO PESO AO NASCER
}

MORTALIDAD NEONATAL EN NIÑOS CON BAJO PESO AL NACER

\author{
Maria Aparecida Munhoz Gaiva ${ }^{1}$, Elizabeth Fujimori ${ }^{2}$, Ana Paula Sayuri Sato ${ }^{3}$
}

\begin{abstract}
Objective: To evaluate the factors associated with neonatal mortality in infant born with low birth weight. Method: Cross-sectional study that analyzed data from 771 live births with low birth weight (<2500 g) in the city of Cuiabá, MT, in 2010, of whom 54 died in the neonatal period. We obtained data from the Information System on Live Births and Mortality, by integrated linkage. Results: In multiple logistic regression, neonatal mortality was associated with: number of prenatal visits less than $7(\mathrm{OR}=3.80 ; \mathrm{Cl}: 1,66-8,70)$; gestational age less than 37 weeks (OR=4.77; Cl:1.48-15.38), Apgar score less than 7 at the $1^{\text {st }}$ minute $(\mathrm{OR}=4.25 ; \mathrm{Cl}: 1.84-9.81)$ and the $5^{\text {th }}$ minute (OR=5.72, $\mathrm{Cl}: 2.24-14.60)$ and presence of congenital anomaly (OR=14.39;IC:2.72-76.09). Conclusion: Neonatal mortality in infants with low birth weight is associated with avoidable factors through adequate attention to prenatal care, childbirth and infants.
\end{abstract}

\section{DESCRIPTORS}

Infant mortality

Risk factors

Infant low birth weight

Information systems

Neonatal nursing

\section{RESUMO}

Objetivo: Avaliar os fatores associados à mortalidade neonatal em crianças nascidas com baixo peso. Método: Estudo transversal que analisou dados de 771 nascidos vivos com baixo peso $(<2.500 \mathrm{~g})$ no município de Cuiabá, MT, em 2010, dos quais 54 foram a óbito no período neonatal. Obtiveramse os dados do Sistema de Informação de Nascidos Vivos e de Mortalidade, integrados por linkage. Resultados: Na regressão logística múltipla, mortalidade neonatal associou-se com: número de consultas prénatal menor que 7 (OR=3,80;IC:1,66-8,70); idade gestacional menor que 37 semanas ( $O R=4,77 ; I C: 1,48-15,38)$, Apgar menor que 7 no 1 을 minuto $(\mathrm{OR}=4,25 ; \mathrm{IC}: 1,84-9,81)$ e 5 응 minuto (OR=5,72;IC:2,24-14,60) e presença de anomalia congênita (OR=14,39;IC:2,72-76,09). Conclusão: A mortalidade neonatal em recém-nascidos com baixo peso associa-se a fatores evitáveis por adequada atenção no pré-natal, parto e ao recém-nascido.

\section{RESUMEN}

Objetivo: Evaluar los factores asociados con la mortalidad neonatal en niños nacidos con bajo peso. Método: Estudio transversal que analizó datos de 771 nacidos vivos con bajo peso $(<2.500 \mathrm{~g})$ en el municipio de Cuiabá, Estado de Mato Grosso, en 2010, de los que 54 fallecieron en el período neonatal. Se obtuvieron los datos del Sistema de Información de Nacidos Vivos y de Mortalidad, integrados por linkage. Resultados: En la regresión logística múltiple, la mortalidad neonatal se asoció con: número de consultas pre natal menor de 7 (OR=3,80;IC:1,66-8,70); edad gestacional menor de 37 semanas (OR=4,77;IC:1,48-15,38), Apgar menor de 7 en el $1^{\text {er }}$ minuto $(O R=4,25 ; \mathrm{IC}: 1,84-9,81)$ y 50 minuto $(\mathrm{OR}=5,72 ; \mathrm{IC}: 2,24-14,60)$; y presencia de anomalía congénita (OR=14,39;IC:2,72-76,09). Conclusión: La mortalidad neonatal en recién nacidos con bajo peso se asocia con factores que se pueden prevenir mediante una adecuada atención en el prenatal, parto y al mismo recién nacido.

\author{
DESCRIPTORES \\ Mortalidad infantil \\ Factores de riesgo \\ Recién nacido de bajo peso \\ Sistemas de información \\ Enfermería neonatal
}

\footnotetext{
${ }_{1}^{1}$ Associate Professor, School of Nursing, Federal University of Mato Grosso, Cuiabá, MT, Brazil.. ${ }^{2}$ Associate Professor, Department of Nursing in Public Health, School of Nursing, University of São Paulo, São Paulo, SP, Brazil. ${ }^{3}$ PhD, Professor, School of Public Health, University of São Paulo, São Paulo, SP, Brazil.
} 


\section{INTRODUCTION}

For the World Health Organization, a low birth weight newborn is an infant who is born weighting less than 2,500 grams. Birth weight is an indicator of greater influence on infant health and survival, as epidemiological data show that an infant born with a weight below this limit have a higher risk of dying, compared to those born with normal weight ${ }^{(1)}$.

The association between mortality and birth weight is inversely proportional, that is, the probability of death decreases as the weight increases. The risk of death among newborns of very low birth weight (less than $1500 \mathrm{~g}$ ) is 30 times higher when compared with those born at 2,500 grams or more ${ }^{(2)}$. In turn, the risk of death among infants with extremely low birth weight (less than $1000 \mathrm{~g}$ weight) is 4.8 times greater than those who are born weighting $1.000 \mathrm{~g}$ to $1.499 \mathrm{~g}^{(3)}$.

In Brazil, about $8 \%$ of total live births have low birth weight ${ }^{(4-5)}$. This group represents more than half of neonatal deaths, especially those who are born with extremely low birth weight ${ }^{(3)}$, confirmed by numerous studies that addresses low birth weight as one of the main factors associated with increased likelihood of death in the neonatal period ${ }^{(2,6-10)}$.

Among the causes for low birth weight, we highlight prematurity and intrauterine growth restriction. Moreover, it is considered that low birth weight is a condition that reflects the quality of maternal care during pregnancy and childbirth ${ }^{(1,4)}$.

There is evidence that neonatal mortality is associated with maternal age, with the highest risks for the extremes of age (adolescents or women who are equal or more than 35 years old), low maternal education, reproductive characteristics and factors related to pregnancy and prenatal assistance as type of labor and perinatal conditions ${ }^{(2,9-10)}$.

Although many studies address the determinants of neonatal mortality in the country, there are only a few which have as population the low birth weight infant, which justifies the design of this study. The aim of this research is to evaluate factors associated with neonatal mortality in infants with low birth weight. The purpose is to contribute to the decrease in neonatal mortality, especially among infants born with this characteristic.

\section{METHOD}

Cross-sectional study using secondary data on births and deaths. The studied population comprised all live births with low birth weight (500-2499 grams) during the period from January $1^{\text {st }}$ to December $31^{\text {st }}$ of the year 2010 and those who died in the neonatal period, that is, in the first 27 days of life. Live birth infants of mothers who are residents in the city of Cuiaba, capital of Mato Grosso State, were included.
Data were obtained from the Live Birth Information System (SINASC) and the Mortality Information System (SIM), provided by the Management of Surveillance of Births and Deaths of the Municipal Health Secretary of Cuiabá, MT, integrated by linkage technique. The choice variable for the junction of the databases was the number of Live Birth Certificates (LBC), for being unique and exclusive for each live birth and be present in LBC and Death Certificate (DC). Three deaths were not located in their respective LBC database (SINASC), so they were excluded from the study. Thus, the successful integration of databases resulted in $96.2 \%$ linking. After that, the matching records from SIM and SINASC were grouped, constituting a single database, used in the present study.

In 2010, from a total of 9.349 births, 771 were of infants with low birth weight (8.3\%). Out of this total, 54 $(7.0 \%)$ died in the neonatal period.

Importantly, in 2010, a new model of LB was implemented in the country, which in Cuiabá occurred from September on. The new fields included were Father (Name and Age) and Congenital anomaly, which in addition to keeping the field to record the presence or absence of the anomaly was added a field for describing the type of anomaly. The race/color variable was deleted from the newborn Identification field. The field Mother had the greatest changes being added data on Race/Color and Date of birth; Education changed from years of education completed [none; 1 to $3 ; 4$ to $7 ; 8$ to $11 ; 12$ and over; ignored] to complete last grade [no education; Elementary school ( $1^{\text {st }}$ to $4^{\text {th }}$ grade); Middle school ( $5^{\text {th }}$ to $8^{\text {th }}$ grade); High school (former $2^{\text {nd }}$ degree); incomplete college; complete college; ignored]; Conjugal status was replaced by Marital Status, including the variable stable relationship. The field Pregnancy and childbirth now includes the variable Previous pregnancies, and in the Current pregnancy field, the main change was in relation to gestational age and number of prenatal visits no longer grouped by range (none, 1 to 3, 4 to 6, 7 or more, ignored). In relation to Childbirth, besides the Type of labor, data on Presentation, Was labor induced?, Did the Cesarean occur before labor had started? and Birth assisted by were added up. The new LB no longer includes the papiloscopy identification of the mother and newborn. Thus, due to the validity of two models of LB in the year studied (2010), there was a high percentage of unknown information/unregistered.

For analysis, it was considered as the dependent variable neonatal death and as independent or exposure variables: maternal and child characteristics (socio demographic and those related to pregnancy, childbirth and newborn), contained in SINASC or SIM: maternal characteristics - age ( $<20$ years or $\geq 20$ ); education (elementary, high school or college education); number of infant alive ( $<2$ or $\geq 2$ ); number of prenatal visits ( $<7$ or $\geq 7$ ), considering the ranges of previous LB and type of labor (vaginal or cesarean); infant characteristics - gender (male or female); gestational age ( $<37$ or $\geq 37$ weeks); Apgar score at the $1^{\text {st }}$ 
and $5^{\text {th }}$ minutes $(<7$ or $\geq 7$ ); presence of congenital anomaly (yes or no); and race/color (white or nonwhite).

The initial analysis of the independent variables associated with neonatal death was calculated by comparison with survivors in univariated analysis. The adjustment of possible confounding variables was performed using multiple logistic regression. To avoid exclusion of potentially important variables, the variables with $p<0.20$ in the univariate analysis were included. The strength of association between the dependent and independent variables was analyzed by odds ratio (OR), both in the univariate analysis (crude OR), and in multiple analysis (adjusted OR). The Hosmer \& Lemeshow (H\&L) test was proposed to check the validity of the model. We used the Statistical Package for Social Sciences (SPSS) for statistical analysis. The significance level for all tests was $5 \%$.

An authorization from the Municipal Health Department was obtained for using the databases and the study was approved by the Research Ethics Committee, under the number 968/CEPHUJM/2010.

\section{RESULTS}

Characterization of low weight infant who died and who survived are presented in Table 1. Among the infants who died, nearly a third were teenage mothers, the vast majority of mothers (79.6\%) of these infants had less than seven prenatal consultations and more than half (55.6\%) had vaginal delivery, maternal characteristics that differed from the observed among survivors $(p<0.05)$.

With regard to infant characteristics, we also found a statistically significant difference $(p<0.05)$ among infants who died and the survivors, with a higher proportion of deaths in males infant born with a gestational age lower than 37 weeks, infant with Apgar score at 1st and 5th minute less than 7 and with presence of congenital malformation (Table 1).

Table 1 - Characteristics of infant with low birth weight with neonatal death and surviving - Cuiabá, MT, 2010

\begin{tabular}{|c|c|c|c|c|}
\hline \multirow[t]{2}{*}{ Maternal characteristics* } & $\begin{array}{c}\begin{array}{c}\text { Deaths } \\
\mathrm{n}=54\end{array} \\
\end{array}$ & $\begin{array}{c}\begin{array}{c}\text { Survivors } \\
\mathbf{n}=717\end{array} \\
\end{array}$ & Total & \multirow[t]{2}{*}{ p-value*: } \\
\hline & $\mathbf{n}(\%)$ & $\mathbf{n}(\%)$ & $\mathbf{n}(\%)$ & \\
\hline Maternal age & & & & 0.035 \\
\hline$<20$ & $16(29.6)$ & $129(18.0)$ & $145(18.8)$ & \\
\hline$\geq 20$ & $38(70.4)$ & $588(82.0)$ & $626(81.2)$ & \\
\hline Maternal education & & & & 0.697 \\
\hline Elementary school ( $<8$ year of study) & $11(20.4)$ & $179(25.0)$ & $190(24.6)$ & \\
\hline High school (8-12 years of study) & $12(22.2)$ & $136(19.0)$ & $148(19.2)$ & \\
\hline College ( $\geq 12$ years of study) & $31(57.4)$ & $402(56.0)$ & $433(56.2)$ & \\
\hline Number of infant alive & & & & 0.939 \\
\hline$<2$ & $35(77.8)$ & $500(77.3)$ & $535(77.3)$ & \\
\hline$\geq 2$ & $10(22.2)$ & $147(22.7)$ & $157(22.7)$ & \\
\hline Ignored & 9 & 70 & 79 & \\
\hline Number of prenatal visits & & & & $<0.001$ \\
\hline$<7$ & $43(82.7)$ & $298(42.0)$ & $341(44.8)$ & \\
\hline$\geq 7$ & $9(17.3)$ & $411(58.0)$ & $420(55.2)$ & \\
\hline Ignored & 2 & 8 & 10 & \\
\hline Type of labor & & & & 0.002 \\
\hline Vaginal & $30(55.6)$ & $248(34.6)$ & $278(36.1)$ & \\
\hline Cesarean & $24(44.4)$ & $469(65.4)$ & $493(63.9)$ & \\
\hline \multicolumn{5}{|l|}{ Infant's characteristics * } \\
\hline Gender & & & & 0.034 \\
\hline Male & $34(63.0)$ & $344(48.0)$ & $378(49.0)$ & \\
\hline Female & $20(37.0)$ & $373(52.0)$ & $393(51.0)$ & \\
\hline Gestational age at birth & & & & $<0.001$ \\
\hline$<37$ & $49(90.7)$ & $433(60.7)$ & $482(62.8)$ & \\
\hline$\geq 37$ & $5(9.3)$ & $280(39.3)$ & $285(37.2)$ & \\
\hline Ignored & 0 & 6 & 4 & \\
\hline 1st minute Apgar & & & & $<0.001$ \\
\hline$<7$ & $35(67.3)$ & $80(11.2)$ & $115(15.0)$ & \\
\hline$\geq 7$ & $17(32.7)$ & $635(88.8)$ & $652(85.0)$ & \\
\hline Ignored & 2 & 2 & 4 & \\
\hline 5th minute Apgar & & & & $<0.001$ \\
\hline$<7$ & $23(43.4)$ & $17(2.4)$ & $40(5.2)$ & \\
\hline$\geq 7$ & $30(56.6)$ & $698(97.6)$ & $728(94.8)$ & \\
\hline Ignored & 1 & 2 & 3 & \\
\hline
\end{tabular}


Continuation...

\begin{tabular}{|c|c|c|c|c|}
\hline \multirow[t]{2}{*}{ Maternal characteristics* } & $\begin{array}{c}\text { Deaths } \\
\mathrm{n}=54\end{array}$ & $\begin{array}{c}\text { Survivors } \\
\mathrm{n}=717\end{array}$ & Total & \multirow[t]{2}{*}{ p-value $* *$} \\
\hline & $\mathbf{n}(\%)$ & $\mathrm{n}(\%)$ & $n(\%)$ & \\
\hline Congenital malformation & & & & 0.001 \\
\hline No & $50(92.6)$ & 707 (98.6) & $757(98.2)$ & \\
\hline Yes & $4(7.4)$ & $10(1.4)$ & $14(1.8)$ & \\
\hline Race/color of the baby & & & & 0.346 \\
\hline White & $12(35.3)$ & $138(27.8)$ & $150(28.2)$ & \\
\hline Not white & $22(64.7)$ & $359(72.2)$ & $381(71.8)$ & \\
\hline Ignored & 20 & 220 & 240 & \\
\hline
\end{tabular}

information was not obtained for all infant and mothers.

${ }^{* *} p$-value refers to the Chi-square test. Note: $n=771$

Univariate analysis showed that neonatal death in infants of low birth weight was associated $(p<0.05)$ with maternal age, number of prenatal visits, delivery type, male gender, Apgar at the 1st and 5th minute $<7$ and the presence of congenital anomalies, variables that were brought to the multiple regression model (Table 2).

Table 2 - Univariate analysis of neonatal deaths among newborns with low birth weight and maternal and infant characteristics Cuiabá, MT, 2010

\begin{tabular}{|c|c|c|c|c|}
\hline \multirow{2}{*}{ Maternal characteristics* } & \multirow{2}{*}{$\mathbf{N}$} & \multirow{2}{*}{$\begin{array}{l}\text { Deaths } \\
\text { n(\%) }\end{array}$} & \multicolumn{2}{|c|}{ Univariate analysis } \\
\hline & & & OR Crude & $95 \%$ IC \\
\hline \multicolumn{5}{|l|}{$\overline{\text { Age }}$} \\
\hline$<20$ & 145 & $16(11.0)$ & 1.92 & $1.04-3.55$ \\
\hline$\geq 20$ & 626 & $38(6.1)$ & 1.00 & \\
\hline \multicolumn{5}{|l|}{ Education } \\
\hline Elementary school ( $<8$ year of study) & 190 & $11(5.8)$ & 0.80 & $0.39-1.62$ \\
\hline High school (8-12 years of study) & 148 & $12(8.1)$ & 1.44 & $0.57-2.29$ \\
\hline College ( $\geq 12$ years of study) & 433 & $31(7.1)$ & 1.00 & \\
\hline \multicolumn{5}{|l|}{ Number of infant alive } \\
\hline$<2$ & 535 & $35(6.5)$ & 1.00 & \\
\hline$\geq 2$ & 157 & $10(6.3)$ & 0.97 & $0.47-2.01$ \\
\hline \multicolumn{5}{|l|}{ Number of prenatal visits } \\
\hline$<7$ & 341 & $43(12.6)$ & 6.60 & $3.16-13.72$ \\
\hline$\geq 7$ & 420 & $9(2.1)$ & 1.00 & \\
\hline \multicolumn{5}{|l|}{ Type of labor } \\
\hline Vaginal & 278 & $30(10.7)$ & 1.00 & \\
\hline Cesarean & 493 & $24(4.8)$ & 2.36 & $1.35-4.13$ \\
\hline \multicolumn{5}{|l|}{ Infant's characteristics * } \\
\hline \multicolumn{5}{|l|}{ Gender } \\
\hline Male & 378 & $34(9.0)$ & 1.84 & $1.04-3.26$ \\
\hline Female & 393 & $20(5.0)$ & 1.00 & \\
\hline \multicolumn{5}{|l|}{ Gestational age at birth } \\
\hline$<37$ & 482 & $49(10.2)$ & 6.34 & $2.49-16.01$ \\
\hline$\geq 37$ & 285 & $5(1.7)$ & 1.00 & \\
\hline \multicolumn{5}{|l|}{ 1st minute Apgar } \\
\hline$<7$ & 115 & $35(30.4)$ & 16.34 & $8.75-30.51$ \\
\hline$\geq 7$ & 652 & $17(2.6)$ & 1.00 & \\
\hline \multicolumn{5}{|l|}{ 5th minute Apgar } \\
\hline$<7$ & 40 & $23(57.5)$ & 31.48 & $15.24-65.04$ \\
\hline$\geq 7$ & 728 & $30(4.1)$ & 1.00 & \\
\hline \multicolumn{5}{|l|}{ Presence of congenital anomaly } \\
\hline No & 757 & $50(6.6)$ & 1.00 & \\
\hline Yes & 14 & $4(28.5)$ & 5.66 & $1.71-18.67$ \\
\hline
\end{tabular}

${ }^{*}$ Information was not obtained for all infant and mothers. Note: $\mathrm{n}=771$

In multiple logistic regression, neonatal mortality was associated with: number of prenatal visits less than $7(\mathrm{OR}=3.80)$; gestational age less than 37 weeks $(\mathrm{OR}=4.77)$; Apgar score less than 7 at the 1st minute
$(O R=4.25)$ and 5 th minute $(O R=5.72)$; and presence of congenital anomalies (OR=14.39). The Hosmer \& Lemeshow test showed adequacy of the final model $(p=0,764)$. 
Table 3 - Multiple analysis of neonatal mortality in infant with low birth weight in the logistic regression model in Cuiabá, MT, 2010

\begin{tabular}{|c|c|c|c|}
\hline \multirow{2}{*}{ Variables } & \multicolumn{2}{|c|}{ Multiple Model } & \multirow{2}{*}{ p-valor } \\
\hline & OR Adjusted & $95 \%$ IC & \\
\hline \multicolumn{4}{|c|}{ Number of prenatal visits } \\
\hline$<7$ & 3.80 & $1.66-8.70$ & 0.002 \\
\hline$\geq 7$ & 1.00 & & \\
\hline \multicolumn{4}{|c|}{ Gestational age at birth } \\
\hline$<37$ & 4.77 & $1.48-15.38$ & 0.010 \\
\hline$\geq 37$ & 1.00 & & \\
\hline \multicolumn{4}{|c|}{ 1st minute Apgar } \\
\hline$<7$ & 4.25 & $1.84-9.81$ & $<0.001$ \\
\hline$\geq 7$ & 1.00 & & \\
\hline \multicolumn{4}{|c|}{ 5th minute Apgar } \\
\hline$<7$ & 5.72 & 2. $24-14.60$ & $<0.001$ \\
\hline$\geq 7$ & 1.00 & & \\
\hline \multicolumn{4}{|c|}{ Presence of congenital anomaly } \\
\hline Yes & 14.39 & $2.72-76-09$ & 0.002 \\
\hline No & 1.00 & & \\
\hline
\end{tabular}

\section{DISCUSSION}

Among infant with low birth weight, prematurity is an important risk factor for neonatal mortality ${ }^{(8,11-13)}$, confirmed in the present study, since the newborns with less than 37 weeks of gestational age were more likely to neonatal death compared to those at term. This value, however, was significantly lower than that observed in the state of Rio Grande do Sul, in a study analyzing the determinants of neonatal mortality in a cohort of 138,407 living newborns and 1,134 neonatal deaths in 2003, where it was found that the chance of death between living newborns with less than 37 weeks of gestational age was 28.9 times higher, compared with newborn term infants ${ }^{(9)}$. It is noteworthy, however, that our study population is small compared to the cited research.

Also in a cohort study of live births weighting between 500 and $2.499 \mathrm{~g}$ developed in the city of Recife, PE, gestational age was associated with neonatal death in the same way that birth weight ${ }^{(8)}$.

Birth weight, besides being an effective prognostic indicator of death is important to explain the effect of social and biological variables in neonatal mortality ${ }^{(14)}$.

Among the biological variables, the low Apgar score has been described in the literature as a predictive variable that is more closely associated with neonatal death ${ }^{(8-9,15)}$, recurrent in the present study, since Apgar score $<7$, both in the $1^{\text {st }}$ and $5^{\text {th }}$ minutes was associated with neonatal death. In Recife-PE, infant born with low birth weight who developed severe hypoxia (Apgar score $0-3$ ) at the $1^{\text {st }}$ and $5^{\text {th }}$ minutes of life had 44 times higher chance of death than those who did not have hypoxia at birth ${ }^{(8)}$. This result was also observed in a study conducted in Londrina$\mathrm{PR}$, where most of those who died in the neonatal period (78.2\%) had been born with low birth weight and asphyxia was presented in the $1^{\text {st }}$ minute of life ${ }^{(12)}$.

Low Apgar score in the $5^{\text {th }}$ minute is considered the most accurate index for the prognosis of neurological health of the child and death. Research that evaluate perinatal factors associated with early death in preterm infants born in eight public university hospitals affiliated with the Brazilian Neonatal Research Network found that the Apgar score between 0 and 6 at the $5^{\text {th }}$ minute was strongly associated with early neonatal death ${ }^{(16)}$. This finding is confirmed by other studies, highlighting a study conducted in the USA, which showed higher correlation between low Apgar score at the $5^{\text {th }}$ minute ( 0 to 6$)$ and neonatal mortality in preterm infants with gestational age of 24 to 28 weeks $^{(17)}$, association also observed in this study $(O R=5.72)$.

The Apgar score, besides presenting the state of vitality of the newborn, is directly associated to quality of care at delivery. Thus, considering that the lower the Apgar score at the $1^{\text {st }}$ and $5^{\text {th }}$ minute of life, the smaller the chances of survival, it is essential to monitor the adequacy of assistance in childbirth and after birth. In this context, an organized obstetric and neonatal network of quality minimizes the risk factors that can lead to hypoxia and neonatal deaths ${ }^{(8)}$.

In this context, we highlight the importance of training the team of health care in cardiopulmonary resuscitation in the delivery room, practice used to prevent asphyxiation and/or perinatal anoxia with irreversible brain impairment, and considered an important tool for reducing neonatal mortality.

Although this study has not analyzed the causes of deaths among low birth weight newborns, we note that these deaths mostly occur due to preventable causes, especially through adequate care to women during pregnancy $^{(18)}$, which reinforces the need to invest in the training of pre-natal care services available in the Brazilian Unified Health System.

Another variable associated with neonatal death in infants of low birth weight was the number of prenatal visits. In fact, absent or inadequate monitoring of pregnancy has been showing to be a risk factor for neonatal mortality ${ }^{(2-3)}$. Association between number of prenatal consultations and neonatal mortality was also observed in a study with a population of live births, nonexclusive of low weight, which we observe a 3.78 times greater risk of death in newborns of mothers with less than seven consultations during pregnancy. The probability of death in newborns of these mothers was 16.8 per thousand, while for those of mothers with more than seven consultations was 4.5 per thousand ${ }^{(7)}$. 
A similar result was found in a study conducted in the city of Recife-PE with live births of low birth weight, in which the largest number of consultations during pregnancy was associated with decreased neonatal mortality ${ }^{(8)}$.

The association between low birth weight and the number of prenatal consultations was not confirmed in research that examined the social, economic, demographic and epidemiological factors associated with underweight and low birth weight infant under two years old, from the data of the National Demographic and Health Research $2006 / 2007^{(19)}$. On the other hand, research that identified the risk factors associated with the birth of newborn of low birth weight in a countryside city in the state of Sao Paulo showed a strong association between the number of prenatal consultations and low birth weight ${ }^{(20)}$.

In the monitoring of pregnancy, the concern should not be limited only to the quantity of consultations, but also the quality of prenatal care, since appropriate care during pregnancy allows early identification of high-risk pregnancies, preventing births of infant with low weight and contributing to the reduction of neonatal mortality ${ }^{(3)}$.

Although congenital anomalies are significantly considered on the statistics of morbidity and infant mortality, representing the second leading cause of neonatal death in $\mathrm{Brazil}^{(21)}$, they have been little explored in mortality studies, most likely because they are not classified as preventable deaths, mostly unknown etiology and therefore, difficult to reduce ${ }^{(18)}$. In the present study, the presence of congenital anomaly was associated with death, with a greater chance of neonatal death compared to those born without malfunction. This association was also observed in a study of newborns with low birth weight ${ }^{(8)}$. But, we emphasize that the congenital anomalies that are registered in LB are diagnosed in the delivery room, some require evaluation and subsequent diagnosis such as heart disease, for example, that are underreported.

Low birth weight is the most important indicator for neonatal mortality ${ }^{(1,5)}$ and this fact has been reaffirmed in many studies conducted in Brazil, an example of research conducted in the south of Brazil, where it was found that those born alive, but with low birth weight were at risk of death 44 times higher than the normal weight births, besides the probability of death of 69.2 per thousand ${ }^{(7)}$. It is noteworthy that, in the present study, we chose to define as low birth weight all infants born with less than $2500 \mathrm{~g}$, without stratification by weight range, despite the likelihood of neonatal death increase with the decrease of birth weight ${ }^{(1,3)}$, a fact that should be considered when interpreting the results.

Thus, as it has occurred in other countries, Brazil has also presented the paradox of low birth weight, that is, higher rates of low birth weight in the geographic areas of greatest socioeconomic development, when reasonably would expect a lower prevalence ${ }^{(4,22-23)}$. The explanations for this paradox still needs to be better investigated, but some causes have been described in the literature, among them, the high use of assisted reproduction techniques in more developed regions and the excessive number of caesarean sections, among others ${ }^{(23)}$.

The inequality in the spatial distribution of low birth weight infants in the country reinforces the need for greater investment in improving health care network and its use throughout the population, to reduce the number of infant deaths and low birth weight ${ }^{(22)}$. In this sense, it is expected that the implementation of Stork Network by the Brazilian Ministry of Health in 2011, which aims to ensure access and problem solving during the prenatal care, childbirth and the neonatal period contribute to reducing newborn deaths in the city of Cuiabá.

Since a considerable portion of low birth weight infants occurs among the newborn preterm, discusses the need to reduce the percentage of premature births to reduce the number of newborns with low weight and thus reduce the neonatal mortality rate ${ }^{(3)}$. Among the interventions found in the literature for preventing premature births and low birth weight, prenatal care quality is highlighted, with monitoring of maternal weight and correction of potential failures in weight gain, in addition to combat smoking and tracking infections of urinary tract during the prenatal ${ }^{(10,24,25)}$. In addition to these measures, rates of prematurity can be reduced with better access to family planning, especially for adolescents, increased empowerment, as well as improving care before and during pregnancy ${ }^{(1)}$.

However, it is essential to consider the social determinants that affect the occurrence of prematurity and low birth weight, and therefore, affecting greater risks for neonatal death. Among these determinants, we highlight maternal age and adverse living conditions, and the low educational level of the mother, among others ${ }^{(1,6,22)}$. Research that assessed infant mortality in newborn of very low birth weight in a public hospital in the city of Rio de Janeiro showed that infant of mothers with less than four years of study had a 2.5 times increased risk of neonatal death in comparison to those whose mothers that had more than eight years of study ${ }^{(14)}$.

Socioeconomic inequalities have an important role in the occurrence of low birth weight and premature birth ${ }^{(6)}$. Maternal social status has close relationship with their education. Thus, low birth weight may be related to the low socioeconomic status of the mothers, which leads to less weight gain in pregnancy, delayed initiation of prenatal care and the number of consultations lower than standard ${ }^{(26)}$.

Despite this evidence, in the present study, maternal sociodemographic characteristics such as age and education were not associated with neonatal death among low birth weight newborns, a situation also found in other studies conducted in the country ${ }^{(12,27)}$. It can be argued that the neonatal mortality suffers more influence on the quality of care provided to mother and child during pregnancy and childbirth, and that socio- 
economic conditions are impacting more directly in post-neonatal mortality.

In this study, no association was found between type of birth and death in low birth weight infants, but it is known that elective caesarean sections and induction of labor has significantly contributed to the increase in the number of premature births and occurrence of low birth weight ${ }^{(19)}$, characteristics also found in other countries in Latin Ameri$\mathrm{ca}^{(28)}$. In Chile, analysis of all living births from 1991 to 2008 showed that, although the rate of $5.3 \%$ of low birth weight, specific trends in low birth weight should be considered, associated with the significant increase in the rate of premature birth (less than 32 weeks of gestational age), and also associated with an increased rate of very low birth weight linked to increased multiple births ${ }^{(28)}$.

One limitation of this study relates to the fact that it is the analysis of secondary data, which depends on the reliability and completeness of filling the records. It is also noteworthy, the introduction of a new model of LB in the year studied, which may explain in part the high percentage of fields without registration. Moreover, it was only possible to evaluate predictive factors that were present in the SINASC database. Thus, important determinants of neonatal mortality and low birth weight, as the quality of prenatal care and maternal social characteristics, such as family income, were not analyzed, since the only variable representative of the socioeconomic level available in SINASC is education.

Information systems play an important role as a source of data, but despite the obvious improvement in coverage

\section{REFERENCES}

1. World Health Organization (WHO). Born too soon: the global action report on preterm birth [Internet]. Geneva; 2012 [cited 2014 June 20]. Available from: http://www.who.int/maternal_child_adolescent/documents/born_too_soon/en/

2. Soares ES, Menezes GMS. Fatores associados à mortalidade neonatal precoce: análise de situação no nível local. Epidemiol Serv Saúde. 2010;19(1):51-60.

3. Almeida MF, Alencar GP, Schoeps D, Novaes HMD, Campbell $\mathrm{O}$, Rodrigues LC. Sobrevida e fatores de risco para mortalidade neonatal em uma coorte de nascidos vivos de muito baixo peso ao nascer, na Região Sul do Município de São Paulo, Brasil. Cad Saúde Pública. 2011;27(6):1088-98.

4. Silva AAM, Silva LM, Barbieri MA, Bettiol H, Carvalho LM, Ribeiro VS, et al. The epidemiologic paradox of low birth weight in Brazil. Rev Saúde Pública. 2010;44(5):767-75.

5. Victora CG, Aquino EML, Leal MC, Monteiro CA, Barros FC, Szwarcwald CL. Maternal and child health in Brazil: progress and challenges. Lancet. 2011;377(9780):1863-76. and quality of SINASC records, failures when filling the LB still occur ${ }^{(29)}$. Thus, for this system to be used as a source of research and evaluation in health, it is necessary to invest in coverage and quality of completion of all variables of the instruments which feeds their bases. The use of the linkage technique between databases, however, proved to be extremely useful and revealed important information that can be used by local managers to face neonatal mortality in infant with low birth weight. Nevertheless, the results indicate that investments should be targeted to improve the completeness and quality of completion of LB, so that information systems can actually be used in the preparation of reliable indicators of maternal and child health in municipalities.

\section{CONCLUSION}

Number of prenatal visits less than 7, gestational age less than 37 weeks, Apgar score less than 7 at the $1^{\text {st }}$ and $5^{\text {th }}$ minute and presence of congenital anomalies are factors associated with neonatal mortality in newborns with low birth weight in Cuiabá corroborating the results of other national researches.

Several of these factors are preventable by appropriate intervention within the health services, which highlights the need for managers and professionals to review the quality of care providing both investments in prenatal care, aiming at the reduction of infant with low birth weight, as in childbirth and in the care for these newborns, fundamental to fight infant and newborn mortality in the city.
6. Glinianaia SV, Ghosh R, Rankin J, Pearce MS, Parker L, PlessMullioli T. No improvement in socioeconomic inequalities in birth weight and preterm birth over four decades: a population-based cohort study. BMC Public Health [Internet]. 2013 [cited 2014 June 22];13:345. Available from: http://www. biomedcentral.com/1471-2458/13/345

7. Maran E, Uchimura TT. Mortalidade neonatal: fatores de risco em um município no sul do Brasil. Rev Eletr Enferm [Internet]. 2008 [citado 2010 set. 29];10(1). Disponível em: http://www. fen.ufg.br/revista/v10/n1/v10n1a03.htm

8. Ribeiro AM, Guimarães MJ, Lima MC, Sarinho SW, Coutinho SB. Fatores de risco para mortalidade neonatal em crianças com baixo peso ao nascer. Rev Saúde Pública. 2009;43(2):246-55.

9. Zanine RR, Moraes AB, Giugliani ERJ, Riboldi J. Determinantes contextuais da mortalidade neonatal no Rio Grande do Sul por dois modelos de análise. Rev Saúde Pública. 2011;45(1):79-89.
Neonatal mortality in infants with low birth weigh Gaiva MAM, Fujimori E, Sato APS 
10. Borba GG, Neves ET, Arrué AM, Silveira A, Zamberlan KC. Fatores associados à morbimortalidade neonatal: um estudo de revisão. Saúde (Santa Maria). 2014;40(1):9-16.

11. Nascimento RM, Leite AJM Almeida NMGS, Almeida PC, Silva CF. Determinantes da mortalidade neonatal: estudo caso-controle em Fortaleza, Ceará, Brasil. Cad Saúde Pública. 2012;28(3):559-72.

12. Ferrari RAP, Bertolozzi MR, Dalmas JC, Girotto E. Determining factors for neonatal mortality in a city in the Southern Region of Brazil. Rev Esc Enferm USP [Internet]. 2013 [cited 2014 June 22];47(3):531-8. Available from: http://www.scielo.br/pdf/reeusp/v47n3/en_0080-6234reeusp-47-3-00531.pdf

13. Barros FC, Matijasevich A, Requejo JH, Giugliani E, Maranhão AG, Monteiro, et al. Recent trends in maternal, newborn, and child health in Brazil: progress toward Millennium Development Goals 4 and 5. Am J Public Health. 2010;100(10):1877-89.

14. Cardoso RCAC, Flores PVG, Vieira CL, Bloch KV, Pinheiro RJ, Fonseca $\mathrm{SC}$, et al. Infant mortality in a very low birth weight cohort from a public hospital in Rio de Janeiro, RJ, Brazil. Rev Bras Saúde Mater Infant. 2013;13(3):237-46.

15. Lima EFA, Sousa Al, Griep RH, Primo CC. Fatores de risco para a mortalidadae neonatal no município de Serra, Espírito Santo. Rev Bras Enferm. 2012;65(4):578-85.

16. Almeida MFB, Guinsburg R, Martinez FE, Procianoy RS, Leone CR, Marba STM, et al. Fatores perinatais associados ao óbito precoce em prematuros nascidos nos centros da Rede Brasileira de Pesquisas Neonatais. J Pediatr (Rio J). 2008;84(4):300-7.

17. Lee HC, Subeh M, Gould JB. Low Apgar score and mortality in extremely preterm neonates born in the United States. Acta Paediatr. 2010;99(12):1785-9.

18. Santos HG, Andrade SM, Silva AMR, Mathias TAF, Ferrari $\mathrm{LL}$, Mesas AE. Mortes infantis evitáveis por intervenções do Sistema Único de Saúde: comparação de duas cortes de nascimentos. Ciênc Saúde Coletiva. 2014;19(3):907-16.

19. Viana KJ, Taddei JAAC, Cocetti M, Warkentin S. Peso ao nascer de crianças brasileiras menores de dois anos. Cad Saúde Pública. 2013;29(2):349-56.
20. Souto da Silva S, Santos FDD, Coca Leventhal L. Nascimento de recém-nascidos de baixo peso em instituição filantrópica terciária do município de Piracicaba. Enferm Global [Internet]. 2011 [citado 2014 jun. 22];10(23):76-88. Disponível em: http://scielo.isciii.es/pdf/eg/v10n23/pt_clinica6.pdf

21. Brasil. Ministério da Saúde. Painel de Monitoramento da Mortalidade Infantil e Fetal. [Internet]. Brasília; 2013 [citado 2013 dez. 10]. Disponível em: http://svs.aids.gov.br/dashboard/mortalidade/infantil.show.mtw

22. Lima MCBN, Oliveira GS, Lyra CO, Ronccalli AG, Ferreira MAF. A desigualdade espacial do baixo peso ao nascer no Brasil. Ciênc Saúde Coletiva. 2013;18(8):2443-52.

23. Matijasevich A, Silveira MF, Matos ACG, Rabello Neto D, Fernandes RM, Maranhão AG, et al. Estimativas corrigidas da prevalência de nascimentos pré-termo no Brasil, 2000 a 2011. Epidemiol Serv Saúde. 2013;22(4):557-64.

24. Sato APS, Fujimori E. Nutritional status and weight gain in pregnant women. Rev Latino Am Enfermagem. 2012;20(3):462-68.

25. Kusuda S, Fujimura M, Uchiyama A, Totsu S, Matsunami K; Neonatal Research Network, Japan. Trends in morbidity and mortality among very-low-birth-weight infants from 2003 to 2008 in Japan. Pediatr Res. 2012;72(5):531-8.

26. Silvestrin S, Silva CH, Hirakata VN, Goldani AAS, Silveira PP, Goldani MZ. Maternal education level and low birth weight: a meta-analysis. J Pediatr (Rio J). 2013;89(4):339-45.

27. Kassar SB, Melo ANC, Coutinho SB, Lima MC, Lira PIC. Determinants of neonatal death with emphasis on health care during pregnancy, childbirth and reproductive history. J Pediatr (Rio J). 2013;89(3):269-77.

28. Lopez P O, Bréart G. Trends in gestational age and birth weight in Chile, 1991-2008. A descriptive epidemiological study. BMC Pregnancy Childbirth [Internet]. 2012 [cited 2014 June 22];12:121. Available from: http://www.ncbi.nlm. nih.gov/pmc/articles/PMC3573962/

29. Silva RS, Oliveira CM, Ferreira DKS, Bonfim CV. Avaliação da completitude das variáveis do Sistema de Informações sobre Nascidos Vivos- SINASC- nos Estados da região Nordeste do Brasil, 2000 e 2009. Epidemiol Serv Saúde. 2013; 22(2):347-52

\section{Financial support:}

National Council for Scientific and Technological Development (CNPq) - Notice No. 14/2012. 